\title{
Lipid Peroxidation and Antioxidant Enzymes Evaluation in Lactating Female Albino Rats Following Supplementation with Fermented Soya Bean and Vitamin C
}

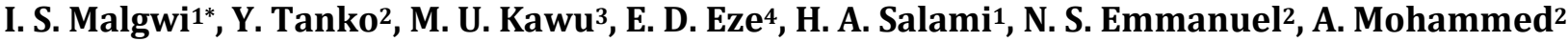 \\ ${ }^{1}$ Department of Human Physiology, College of Medical Sciences, University of Maiduguri, Borno, Nigeria \\ ${ }^{2}$ Department of Human Physiology, Faculty of Medicine, Ahmadu Bello University, Zaria, Nigeria \\ ${ }^{3}$ Department of Veterinary Physiology, Faculty of Veterinary Medicine, Ahmadu Bello University, Zaria, Nigeria \\ ${ }^{4}$ Department of Physiology, Faculty of Biomedical Sciences, Kampala International University, Kampala, Uganda \\ Email: ^ibmalgwi2000@yahoo.com
}

How to cite this paper: Malgwi, I.S., Tanko, Y., Kawu, M.U., Eze, E.D., Salami, H.A., Emmanuel, N.S. and Mohammed, A. (2017) Lipid Peroxidation and Antioxidant Enzymes Evaluation in Lactating Female Albino Rats Following Supplementation with Fermented Soya Bean and Vitamin C. $A d$ vances in Enzyme Research, 5, 24-31. https://doi.org/10.4236/aer.2017.52003

Received: March 24, 2017

Accepted: June 18, 2017

Published: June 21, 2017

Copyright $\odot 2017$ by authors and Scientific Research Publishing Inc. This work is licensed under the Creative Commons Attribution International License (CC BY 4.0).

http://creativecommons.org/licenses/by/4.0/

\begin{abstract}
In mammals, lactation is the most energetically demanding period of a female's reproductive life. This study was designed to evaluate the effect of fermented Soya bean and Vitamin C supplement on lipid peroxidation and antioxidant enzymes in lactating albino rats. Thirty five (35) adult female rats were used for this study. At parturition, the animals were randomly divided into five groups of five (5) rats each. Except group four (4) that was subdivided into three (3) sub groups of five animals each $(n=5)$. Treatment was carried out as follows: Group I: (Normal control) was given normal feed and distilled water, orally ( $1 \mathrm{ml} / \mathrm{kg}$ ), Group II: metoclopramide ( $5 \mathrm{mg} / \mathrm{kg}$ ), Group III: $100 \mathrm{mg} / \mathrm{kg}$ of Vitamin C. The three (3) sub groups under group four (4) received $10 \%, 20 \%$ and $40 \%$ soya bean, respectively, Group V: was co-administered with $20 \%$ soya bean supplement and Vitamin C (100 mg/kg). Treatment was done for the period of ten (10) days at 06:00 h daily. Although there was an increase in serum MDA concentrations in all the treated groups compared to the control, lipid peroxidation was however significantly higher $(\mathrm{P}<$ 0.05 ) in the metoclopramide group relative to the soya bean supplemented groups. This study has shown that supplementation with soya bean induces a mild antioxidant effect by increasing serum level of superoxide dismutase. There was however a significant decrease in serum SOD in the 10\% SB group compared to the control. There was a significant difference in serum catalase activity in the group treated with METCL (46.20 \pm 1.53$)$, SB $10 \%(44.00 \pm$ $1.14)$ and SB $20 \%(45.20 \pm 1.28)$ compared to the control $(52.00 \pm 0.71)(\mathrm{P}<$ 0.05). Serum level of glutathione peroxidase GPx showed a significant difference in the group treated with VIT C, SB $10 \%$ and SB $20 \%$ compared to the
\end{abstract}


control $(\mathrm{P}<0.05)$.

\section{Keywords}

Soya Bean, Lactation, Vitamin C, Lipid Peroxidation, Antioxidant Enzymes

\section{Introduction}

Milk production is essential for optimal feeding of infants and has a direct impact on growth, development, and health in neonatal period [1]. Mammalian cells have complex defiance mechanisms for radical detoxification. Antioxidants are agents which scavenge the free radicals and prevent the damage caused by them. A number of these compounds are of exogenous nature and are obtained from food. Examples include antioxidants like a-tocopherol, B-carotene, and ascorbic acid, and some micro nutrient elements such as zinc and selenium [2]. Oxidative stress (OS) is considered a metabolic disturbance that affects organ systems and its presence will affect not only the health status of the animals but also the quality and quantity of the final products, such as milk [3]. There is evidence that oxidative damage increases during lactation in some domesticated and laboratory animals [4]. The soya bean is native to the Korean Peninsula and the Manchurian area, and soybean has been one of the major sources of protein in Korean food [5]. Numerous foods are made by soybeans, including doenjang (soya bean paste), ganjang (soya bean source), cheonggukjang (fast-fermented bean paste), bean curd, soybean milk, and bean-curd dregs [6]. Soybean consumption is effective for the prevention of osteoporosis, arteriosclerosis, strokes and dementia, and can reduce the risk of cancer and obesity [5]. Therefore, the present study was aimed at evaluating the effect of fermented Soya bean and Vitamin C supplement on lipid peroxidation and antioxidant enzymes in lactating albino rats.

\section{Materials and Methods}

\subsection{Experimental Design}

\subsubsection{Experimental Site}

The study was carried out in the Department of Human Physiology, Faculty of Medicine, Ahmadu Bello University, Zaria. Zaria. Zaria is at an altitude of $670 \mathrm{~m}$ above the sea level and $664 \mathrm{~km}$ away from the sea, in the Northern Guinea Savanna zone. The average rainfall in Zaria is approximately $1000 \mathrm{~mm}$, mainly during the month of March to October. The maximum ambient temperature range in Zaria is $27^{\circ} \mathrm{C}-35^{\circ} \mathrm{C}$ with a dry and wet season. The experiment was carried out during the hot-humid (rainy) season (June-July, 2011) at the Department of Veterinary Physiology and Pharmacology, Ahmadu Bello University, Zaria $\left(11^{\circ} 10^{\prime} \mathrm{N}, 07^{\circ} 38^{\prime} \mathrm{E}\right)$, at the elevation of $650 \mathrm{~m}$ above sea level, located in the Northern Guinea Savannah zone of Nigeria [7].

\subsubsection{Animal Grouping and Drug Administration}

Group I: (Normal control) was given normal vital feed pellets and distilled wa- 
ter, orally ( $1 \mathrm{ml} / \mathrm{kg}$ ), Group II: metoclopramide ( $5 \mathrm{mg} / \mathrm{kg}$ ), Group III: $100 \mathrm{mg} / \mathrm{kg}$ of Vitamin C. The three (3) sub groups under group four (4) received 10\%, 20\% and $40 \%$ soya bean, respectively, Group V: was co-administered with $20 \%$ soya bean supplement and Vitamin C $(100 \mathrm{mg} / \mathrm{kg})$. Administration was carried out orally for a period of ten (10) days. Ethical approval was obtained from the ethical committee of Ahmadu Bello University, Zaria on animal handling, consistent with standard animal welfare guideline,

\subsection{Sample Collection}

At the termination of experiment, the rats were anaesthetized by chloroform inhalation in a closed chamber and blood samples obtained via cardiac puncture into specimen bottles and allowed to clot and separated by centrifugation at 2000 $\times \mathrm{g}$ for 10 minutes using Centrifuge Hettich (Universal 32, Made in Germany) at an average room temperature of $23^{\circ} \mathrm{C}$ and the supernatant obtained was used for biochemical assays.

\subsection{Biochemical Assay}

\subsubsection{Serum Malondialdehyde Assay}

Malondialdehyde (MDA) is one of many low molecular weight end-products of lipid hydroperoxide decomposition and is the most often measured as an index of lipid peroxidation. Malondialdehyde (MDA) activity was estimated using The NWLSS $^{\text {tw }}$ Malondialdehyde assay kits (Northwest Life Sciences Specialies, Product NWK-MDA01, Vancouver WA, Specificity: Malondialdehyde, Sensitivity: $0.08 \mu$ ) based on the method adapted by [8]. The test principle is based on the reaction of MDA with thiobarbituric acid (TBA); forming an MDA-TBA2 adduct that absorbs strongly at $532 \mathrm{~nm}$

\subsubsection{Serum Superoxide Dismutase Assay}

Superoxidase Dismutase (SOD) activity was assayed using the North West Life Science Specialties $\left(\mathrm{NWLSS}^{\mathrm{m}}\right.$ ) SOD assays kit (Product NWK-SOD02, Specificity: $\mathrm{Cu} / \mathrm{Zn}, \mathrm{Mn}$ and Fe Superoxide Dismutase, Sensitivity: $5 \mathrm{U} / \mathrm{mL}$ ). The method is based on the principle of superoxide inhibition of auto-oxidation rate of hematoxylin as originally described by [9], with modifications to increase robustness and reliability. Briefly, $920 \mu \mathrm{L}$ of assay buffer was added to each cuvette. This was followed by addition of $40 \mu \mathrm{L}$ of assay buffer (for blank) and $40 \mu \mathrm{L}$ of sample. The mixture was incubated for two (2) minutes. After which $40 \mu \mathrm{L}$ hematoxylin reagent was added and mixed quickly to start the auto-oxidation reaction. An absorbance was measured at $560 \mathrm{~nm}$ for every 10 seconds for 5 minutes.

\subsubsection{Serum Catalase Assay}

Catalase (CAT) activity was estimated North West Life Science Specialties $\left(\mathrm{NWLSS}^{\mathrm{rm}}\right.$ ) NWLSS ${ }^{\mathrm{TM}}$ Catalase assay kits (Product NWK-CATO1, Specificity: 6.0 $\mathrm{U}$ Catalase $/ \mathrm{mL}$ ) based on the method of [10] with modifications to increase robustness and convenience. The principle is based on monitoring the consumption of $\mathrm{H}_{2} \mathrm{O}_{2}$ substrate at $240 \mathrm{~nm}$. Briefly, to a clean cuvette, $1000 \mu \mathrm{L}$ of sample 
dilution buffer was added and placed in the reference cuvette holder and the wavelength of spectrophotometer was set to $240 \mathrm{~nm}$. To a clean semi-micro UV cuvette, $950 \mu \mathrm{L}$ of working assay buffer was added. $50 \mu \mathrm{L}$ of diluted standard or sample was pippetted to the cuvette and mixed as quickly as possible by repeated pipetting (About 10 times) with the same pipette tip. An absorbance was measured immediately at $240 \mathrm{~nm}$.

\subsubsection{Serum Glutathione Peroxidase Activity (GPx) Assay}

Glutathione peroxidase (GPx) activity was assessed using North West Life Science Specialties (NWLSS ${ }^{\mathrm{ma}}$ ) cGPx (GPX1) ELISA kit (Product NWK-GPX02, Specificity: Gluthathione peroxidase, Sensitivity: $12.5 \mathrm{pg} / \mathrm{ml}$ ) based on the method described by [11]. The assay is based on a sandwich Enzyme-Linked Immunosorbent Assay, where sample GPx concentration was determined by comparing the $450 \mathrm{~nm}$ absorbance sample wells to the absorbance of known standards.

\subsection{Statistical Analysis}

All data were expressed as mean \pm standard error of the mean (mean \pm SEM). Statistical significance was carried out using one way analysis of variance (ANOVA) followed by Tukey's post-hoc test. All statistical analysis was evaluated using SPSS version 20.0 software and Microsoft Excel (2007). Values of P < 0.05 were considered significant.

\section{Results}

\subsection{Effect of ten (10) Days Administration of Soya Bean Supplement and Vitamin C on Biomarker of Lipid Peroxidation; Malondialdehyde (MDA) Level in Female Lactating Wistar Rats}

Serum MDA in female lactating Wistar rats treated with Soya bean supplement and Vitamin C were as follows: METCL ( $1.78 \pm 0.15$ vs $1.32 \pm 0.11)$, VIT C ( 1.52 \pm 0.09 vs $1.32 \pm 0.11)$, SB $10 \%$ ( $1.42 \pm 0.11$ vs $1.32 \pm 0.11)$, SB $20 \%(1.60 \pm 0.07$ vs $1.32 \pm 0.11)$, SB $40 \%(1.40 \pm 0.05$ vs $1.32 \pm 0.11)$ and SB $20 \%+$ VIT C ( $1.40 \pm$ $0.07 \pm 1.32 \pm 0.11)$. There was a significant difference in the group treated with METCL $(5 \mathrm{mg} / \mathrm{kg})$ compared to the control $(\mathrm{P}<0.05)$.

\subsection{Effect of Ten (10) Days Administration of Soya Bean Supplement and Vitamin C on Superoxide Dismutase (SOD) Level in Female Lactating Wistar Rats}

Serum SOD in female lactating Wistar rats treated with Soya bean supplement and Vitamin C were as follows: METCL ( $1.88 \pm 0.07$ vs $2.24 \pm 0.09)$, VIT C (2.08 \pm 0.10 vs $2.24 \pm 0.09)$, SB $10 \%$ ( $1.74 \pm 0.10$ vs $2.24 \pm 0.09)$, SB $20 \%$ ( $1.84 \pm 0.05$ vs $2.24 \pm 0.09)$, SB $40 \%(2.30 \pm 0.13$ vs $2.24 \pm 0.09)$ and SB $20 \%+$ VIT C (1.96 \pm 0.12 vs $2.24 \pm 0.09)$. There was a significant difference in the group treated with SB $10 \%$ compared to the control $(\mathrm{P}<0.05)$. 


\subsection{Effect of Ten (10) Days Administration of Soya Bean Supplement and Vitamin C on Serum Catalase (CAT) Level in Female Lactating Wistar Rats}

Serum CAT in female lactating Wistar rats treated with Soya bean supplement and Vitamin C were as follows: METCL ( $46.20 \pm 1.53$ vs $52.00 \pm 0.71)$, VIT C $(46.80 \pm 1.59$ vs $52.00 \pm 0.71)$, SB $10 \%(44.00 \pm 1.14$ vs $52.00 \pm 0.71)$, SB $20 \%$ (45.20 \pm 1.28 vs $52.00 \pm 0.71)$, SB $40 \%(50.40 \pm 1.17$ vs $52.00 \pm 0.71)$ and SB $20 \%$ + VIT C $(48.20 \pm 1.02$ vs $52.00 \pm 0.71)$. There was a significant difference in the group treated with METCL $(5 \mathrm{mg} / \mathrm{kg}$ ), SB $10 \%$ and SB $20 \%$ compared to the control $(\mathrm{P}<0.05)$.

\subsection{Effect of Ten (10) Days Administration of Soya Bean Supplement and Vitamin C on Glutathione Peroxidase (GPx) Level in Female Lactating Wistar Rats}

Serum GPx in female lactating Wistar rats treated with Soya bean supplement and Vitamin C were as follows: METCL (44.20 \pm 1.56 vs $48.40 \pm 0.93)$, VIT C ( $42.60 \pm 0.93$ vs $48.40 \pm 0.93)$, SB $10 \%(41.60 \pm 1.50$ vs $48.40 \pm 0.93)$, SB $20 \%$ ( $42.60 \pm 1.50$ vs $48.40 \pm 0.93), \mathrm{SB} 40 \%$ ( $48.00 \pm 0.94$ vs $48.40 \pm 0.93)$ and SB $20 \%$ + VIT C (45.80 \pm 0.86 vs $48.40 \pm 0.93)$. There was a significant difference in the group treated with VIT C, SB 10\%and SB 20\% compared to the control (P < $0.05)$.

\section{Discussion}

The result of this present study from Table 1, on the level of serum MDA shows a significant increase in the group treated with metoclopramide compared to the control. This result could be due to the effect of metoclopramide on the poly unsaturated fatty acids along the membrane of the hepatocytes and other susceptible cells, resulting in lipid peroxidation and subsequent formation of the by product; malondialdehyde (MDA). The group treated with $20 \%$ SB showed an increase in the level of serum MDA compared to the other treated groups. This could also be due to a possible pro activity of the supplement on oxidants re-

Table 1. Effect of administration of Soya bean supplement and Vitamin C for 10 days on Serum MDA (Lipid peroxidation) level in female lactating Wistar rats.

\begin{tabular}{cc}
\hline TREATMENT GROUPS & MDA $(\mu \mathrm{mol} / \mathrm{L})$ \\
\hline Control $(1 \mathrm{mg} / \mathrm{kg}$ Normal saline & $1.32 \pm 0.11$ \\
Metoclopramide $(5 \mathrm{mg} / \mathrm{kg})$ & $1.78 \pm 0.15^{*}$ \\
Vitamin C $(100 \mathrm{mg} / \mathrm{kg})$ & $1.52 \pm 0.09$ \\
Soya Bean supplement $(10 \%)$ & $1.42 \pm 0.11$ \\
Soya Bean supplement $(20 \%)$ & $1.60 \pm 0.07$ \\
Soya Bean supplement $(40 \%)$ & $1.40 \pm 0.05$ \\
Soya Bean supplement $(20 \%)+$ Vitamin C $(100 \mathrm{mg} / \mathrm{kg})$ & $1.40 \pm 0.07$
\end{tabular}

$\pm=$ SEM; Means with superscripts $\left({ }^{*}\right)$ within columns are statistically significant $(P<0.05)$ compared to the control. 
sulting in increased lipid peroxidation of cells. It could have also been due to the inability of the supplement at this concentration to effectively break the lipid peroxidation chain reaction. However, the increase was not significant compared to metoclopramide treated and the control. Superoxide dismutase (SOD) as shown in Table 2, showed a decrease in the metoclopramide treated group compared to the control, although not statistically significant. This result could be due to the depletion of the endogenous antioxidant as a result of its utilization in combating the existing oxidative stress as suggested by the level of increased MDA in metoclopramide treated group. The result also could have been due to the inability of metoclopramide to stimulate the release of endogenous antioxidants as well as its tendency to cause increase in reactive oxygen species (ROS) within the system. There was however, a remarkable increase in SOD level, in the Vitamin C treated group as shown in Table 2, which could have been be due to its antioxidant activity. The increase was however, rivaled by that of the SB $40 \%$, which showed the highest increase in serum SOD level. This result is suggestive of SB $40 \%$ as having an antioxidant activity more than the standard anti-oxidant or possibly a more lasting effect than that of vitamin C. This anti-oxidant activity of the supplement on serum SOD level could be attributed to the presence of isoflavones. The result of the co-administration of SB and vitamin $C$ increased the level of SOD more than when the supplement was given singly in the $10 \%$ and $20 \%$ treated groups as shown in Table 2 . This suggests that the co-administration of the supplement and vitamin $\mathrm{C}$ could be more potent than the supplement alone at lower doses of $10 \%$ and $20 \%$. In Table 3, there was a statistically significant decrease in the level of catalase observed in the metoclopramide, and the supplement treated groups at $10 \%$ and $20 \%$. This result could suggest the inability of metoclopramide and the supplement at $10 \%$ and $20 \%$ to specifically augment the release of endogenous catalase enzyme when compared to the activity of the supplement at $40 \%$. Table 4 shows the result of glutathione peroxidase enzyme. The result shows a statistically significant decrease in the level of GPx in the supplement treated groups at $10 \%$ and $20 \%$ and

Table 2. Effect of administration of Soya bean supplement and vitamin C for 10 days on Serum Antioxidant enzyme; Superoxide dismutase (SOD) in female lactating Wistar rats.

\begin{tabular}{cc}
\hline TREATMENT GROUPS & SOD (IU/L) \\
\hline Control $(1 \mathrm{mg} / \mathrm{kg}$ Normal saline & $2.24 \pm 0.09$ \\
Metoclopramide $(5 \mathrm{mg} / \mathrm{kg})$ & $1.88 \pm 0.07$ \\
Vitamin C $(100 \mathrm{mg} / \mathrm{kg})$ & $2.08 \pm 0.10$ \\
Soya Bean supplement $(10 \%)$ & $1.74 \pm 0.10^{*}$ \\
Soya Bean supplement $(20 \%)$ & $1.84 \pm 0.05$ \\
Soya Bean supplement $(40 \%)$ & $2.30 \pm 0.13$ \\
Soya Bean supplement $(20 \%)+$ Vitamin C $(100 \mathrm{mg} / \mathrm{kg})$ & $1.96 \pm 0.12$
\end{tabular}

$\pm=$ SEM; Means with superscripts $\left(^{*}\right)$ within columns are statistically significant $(\mathrm{P}<0.05)$ compared to the control. 
Table 3. Effect of administration of Soya bean supplement and vitamin C for 10 days on Serum Antioxidant enzyme; Catalase (CAT) in female lactating Wistar rats.

\begin{tabular}{cc}
\hline TREATMENT GROUPS & CAT (IU/L) \\
\hline Control $(1 \mathrm{mg} / \mathrm{kg}$ Normal saline & $52.00 \pm 0.71$ \\
Metoclopramide $(5 \mathrm{mg} / \mathrm{kg})$ & $46.20 \pm 1.53^{*}$ \\
Vitamin C (100 mg/kg) & $46.80 \pm 1.59$ \\
Soya Bean supplement (10\%) & $44.00 \pm 1.14^{*}$ \\
Soya Bean supplement (20\%) & $45.20 \pm 1.28^{*}$ \\
Soya Bean supplement (40\%) & $50.40 \pm 1.17$ \\
Soya Bean supplement $(20 \%)+$ Vitamin C $(100 \mathrm{mg} / \mathrm{kg})$ & $48.20 \pm 1.02$ \\
\hline
\end{tabular}

$\pm=$ SEM; Means with superscripts $\left({ }^{*}\right)$ within columns are statistically significant $(\mathrm{P}<0.05)$ compared to the control.

Table 4. Effect of administration of Soya bean supplement and vitamin C for 10 days on Serum Antioxidant enzyme; Glutathione Peroxidase (GPx) in female lactating Wistar rats

\begin{tabular}{cc}
\hline TREATMENT GROUPS & GPx (IU/L) \\
\hline Control $(1 \mathrm{mg} / \mathrm{kg}$ Normal saline & $48.40 \pm 0.93$ \\
Metoclopramide $(5 \mathrm{mg} / \mathrm{kg})$ & $44.20 \pm 1.46$ \\
Vitamin C (100 mg/kg) & $42.60 \pm 0.93^{*}$ \\
Soya Bean supplement (10\%) & $41.60 \pm 1.50^{*}$ \\
Soya Bean supplement (20\%) & $42.60 \pm 1.50^{*}$ \\
Soya Bean supplement (40\%) & $48.00 \pm 0.94$ \\
Soya Bean supplement $(20 \%)+$ Vitamin C $(100 \mathrm{mg} / \mathrm{kg})$ & $45.80 \pm 0.86$ \\
\hline
\end{tabular}

$\pm=$ SEM; Means with superscripts $\left({ }^{*}\right)$ within columns are statistically significant $(\mathrm{P}<0.05)$ compared to the control.

also that of vitamin c. This result suggests that the supplement at these concentrations also do not seem have antioxidant activity, specifically on GPx release or synthesis.

\section{Conclusion}

In summary, metoclopramide at $5 \mathrm{mg} / \mathrm{kg}$ has increased lipid peroxidation according to this study and the supplement at $40 \%$ showed an increase in antioxidant capacity when compared to the control and the other treated groups.

\section{References}

[1] Felipe, P.T., Juleana, V.B.J. and Zulma T.R. (2014) Pharmacological Overview of Galactogogues. Veterinary Medicine International, 66, 505-511.

[2] Halliwell, B. and Gutteridge, J.M.C. (1998) The Antioxidants of Human Extracellular Fluids. Archives of Biocmistry and Biophysics Impact Factor, 280-218.

[3] Castillo, C., Hernández, J. and Valverde, I. (2006) Plasma Malonaldehyde (MDA) and Total Antioxidant Status (TAS) during Lactation in Dairy Cows. Research in Veterinary Science, 80, 133-139. https://doi.org/10.1016/j.rvsc.2005.06.003 
[4] Upreti, K., Chaki, S.P. and Misro, M.M. (2002) Evaluation of Peroxidative Stress and Enzymatic Antioxidant Activity in Liver and Kidney during Pregnancy and Lactation in Rats. Health Population Perspective Issues, 25, 177-185.

[5] Kim, G.Y., Moon, H.K., Lee, S.W., Moon, J.N. and Yoon, W.J. (2010) Effect of Mixed Soybeans Materials on Quality Characteristics of Traditional Soybean Paste (Doenjang) during Aging. Korean Journal of Food and Cookery Science, 26, 314322.

[6] Yoo, K.M., Hwang, J.Y. and Lee, S.M. (2011) Development of Soybean Snacks and Analysis of Bioactive Compounds. Korean Journal of Food and Nutrition, 24, 702707. https://doi.org/10.9799/ksfan.2011.24.4.702

[7] Marthins, M.I. (2006) Zaria and Its Regions. Ahmadu Bello University, Zaria, 41.

[8] Janero, D.R. (1990) Malondialdehyde and Thiobarbituric Acid-Reactivity as Diagnostic Indices of Lipid Peroxidation and Peroxidative Tissue Injury. Free Radical Biology and Medicine, 9, 515-540. https://doi.org/10.1016/0891-5849(90)90131-2

[9] Martin, J.P., Daily, M. and Sugarrnan, E. (1987) Negetive and Positive Assay of Superoxide Dismutase Based on Hematoxylin Autoxidation. Archives of Biochemistry and Biophysics, 255, 329-336. https://doi.org/10.1016/0003-9861(87)90400-0

[10] Beers, R.F. and Sizer, I.W. (1952) A Spectrophotometric Method for Measuring the Breakdown of Hydrogen Peroxide by Catalase. Journal of Biological Chemistry, 195, 133-140.

[11] Avissar, N., Eisenmann, C. and Breen, J.G. (1994) Human Placenta Makes Extracellular Glutathione Peroxidase Secretes It into Maternal Circulation. American Journal of Physiology, 267, 68-76.

\section{Submit or recommend next manuscript to SCIRP and we will provide best service for you:}

Accepting pre-submission inquiries through Email, Facebook, LinkedIn, Twitter, etc. A wide selection of journals (inclusive of 9 subjects, more than 200 journals)

Providing 24-hour high-quality service

User-friendly online submission system

Fair and swift peer-review system

Efficient typesetting and proofreading procedure

Display of the result of downloads and visits, as well as the number of cited articles

Maximum dissemination of your research work

Submit your manuscript at: http://papersubmission.scirp.org/

Or contact aer@scirp.org 